University of Nebraska - Lincoln

DigitalCommons@University of Nebraska - Lincoln

2008

\title{
A General and Rapid Cell-Free Approach for the Interrogation of Protein-Protein, Protein-DNA, and Protein-RNA Interactions and their Antagonists Utilizing Split-Protein Reporters
}

\author{
Jason R. Porter \\ University of Arizona, jason.porter@ucsf.edu \\ Cliff I. Stains \\ University of Nebraska-Lincoln, cstains2@unl.edu \\ Benjamin W. Jester \\ University of Arizona, bjester@email.arizona.edu \\ Indraneel Ghosh \\ University of Arizona, ghosh@email.arizona.edu
}

Follow this and additional works at: https://digitalcommons.unl.edu/chemistrystains

Part of the Chemistry Commons

Porter, Jason R.; Stains, Cliff I.; Jester, Benjamin W.; and Ghosh, Indraneel, "A General and Rapid Cell-Free Approach for the Interrogation of Protein-Protein, Protein-DNA, and Protein-RNA Interactions and their Antagonists Utilizing Split-Protein Reporters" (2008). Cliff Stains Publications. 6.

https://digitalcommons.unl.edu/chemistrystains/6

This Article is brought to you for free and open access by the Published Research - Department of Chemistry at DigitalCommons@University of Nebraska - Lincoln. It has been accepted for inclusion in Cliff Stains Publications by an authorized administrator of DigitalCommons@University of Nebraska - Lincoln. 


\title{
A General and Rapid Cell-Free Approach for the Interrogation of Protein-Protein, Protein-DNA, and Protein-RNA Interactions and their Antagonists Utilizing Split-Protein Reporters
}

\author{
Jason R. Porter, Cliff I. Stains, Benjamin W. Jester, and Indraneel Ghosh \\ Department of Chemistry, University of Arizona, Tucson, Arizona 85721 \\ Corresponding author — I. Ghosh, ghosh@email.arizona.edu
}

\begin{abstract}
Split-protein reporters have emerged as a powerful methodology for imaging biomolecular interactions which are of much interest as targets for chemical intervention. Herein we describe a systematic evaluation of split-proteins, specifically the green fluorescent protein, $\beta$-lactamase, and several luciferases, for their ability to function as reporters in completely cell-free systems to allow for the extremely rapid and sensitive determination of a wide range of biomolecular interactions without the requirement for laborious transfection, cell culture, or protein purification ( $12-48 \mathrm{~h})$. We demonstrate that the cell-free split-luciferase system in particular is amenable for directly interrogating protein-protein, protein-DNA, and protein-RNA interactions in homogeneous assays with very high sensitivity (22-1800 fold) starting from the corresponding mRNA or DNA. Importantly, we show that the cell-free system allows for the rapid (2 h) identification of target-site specificity for protein-nucleic acid interactions and in evaluating antagonists of protein-protein and protein-peptide complexes circumventing protein purification bottlenecks. Moreover, we show that the cell-free split-protein system is adaptable for analysis of both protein-protein and protein-nucleic acid interactions in artificial cell systems comprising water-in-oil emulsions. Thus, this study provides a general and enabling methodology for the rapid interrogation of a wide variety of biomolecular interactions and their antagonists without the limitations imposed by current in vitro and in vivo approaches.
\end{abstract}

\section{Introduction}

Protein-protein ${ }^{1}$ and protein-nucleic acid ${ }^{2}$ interactions are central to cellular function and are also emerging targets for pharmacological intervention when implicated in a particular disease pathway. Thus numerous in vitro and in vivo methods have been developed to target ${ }^{3-7}$ and study these biomolecular interactions. Widely utilized in vitro methods for interrogating protein-protein and protein-DNA interactions and their antagonists include variations of enzyme linked immunosorbent assays (ELISAs), surface plasmon resonance (SPR), and fluorescence polarization (FP), which either require the use of antibodies or purified proteins and often require chemical derivatization. On the other hand powerful in vivo methods such as yeast two-hybrid ${ }^{8}$ assays have the advantage of speed by eliminating the need for protein purification but can be subject to false positives and negatives due to the multifactorial nature of signal generation. ${ }^{9}$ In between these two extremes lie protein fragment based methods, where a specific biomolecular interaction drives the reassembly of a previously split reporter protein ${ }^{10}$ (Figure 1).

The reconstitution of a functional protein from split-peptide fragments was first demonstrated for ribonuclease in 1959. ${ }^{11}$ Since then "split-protein reassembly" or "protein complementation" has been applied to the in vivo detection of a wide variety of protein-protein interactions utilizing numerous split-proteins including ubiquitin, ${ }^{12} \beta$-galactosidase, ${ }^{13} \mathrm{di}^{-}$ hydrofolate reductase, ${ }^{14} \beta$-lactamase, ${ }^{15}$ GFP, ${ }^{16}$ GFP-variants and analogues, ${ }^{17-19}$ firefly luciferase, ${ }^{20}$ and Gaussia luciferase. ${ }^{21}$ Recently, we and others have also described methods for detecting nucleic acids and their chemical modification by the reassembly of ternary complexes of split-GFP and split- $\beta$ lactamase tethered to nucleic acid binding proteins. ${ }^{22-27}$ Thus split-protein systems or "protein complementation assays" (PCAs) can directly image most biomolecular interactions. Although the current methods are of great utility, all of the cur-
1. Wells, J. A., and McClendon, C. L. Nature 2007450 1001-1009

2. Hurley, L. H. Nat. Rev. Cancer $20022188-200$

3. Braisted, A. C., Oslob, J. D., Delano, W. L., Hyde, J., McDowell, R. S., Waal, N., Yu, C., Arkin, M. R., and Raimundo, B. C. J. Am. Chem. Soc. 2003125 3714-3715

4. Chin, J. W., and Schepartz, A. Angew. Chem., Int. Ed. 200140 3806-3809

5. Ding, K., Lu, Y., Nikolovska-Coleska, Z., Qiu, S., Ding, Y. S., Gao, W., Stuckey, J., Krajewski, K., Roller, P. P., Tomita, Y., Parrish, D. A., Deschamps, J. R., and Wang, S. M. J. Am. Chem. Soc. 2005127 10130-10131

6. Orner, B. P., Ernst, J. T., and Hamilton, A. D. J. Am. Chem. Soc. 2001 $1235382-5383$
7. Rajagopal, S., Meyer, S. C., Goldman, A., Zhou, M., and Ghosh, I. J. Am. Chem. Soc. 2006128 14356-14363

8. Fields, S., and Song, O. Nature 1989340 245-246

9. Fields, S. FEBS J. 2005272 5391-5399

10. Michnick, S. W., Ear, P. H., Manderson, E. N., Remy, I., and Stefan, E. Nat. Rev. Drug Discovery 20076 569-582

11. Richards, F. M., and Vithayathil, P. J. J. Biol. Chem. 1959234 1459-1465

12. Johnsson, N., and Varshavsky, A. Proc. Natl. Acad. Sci. U.S.A. 1994 91 10340-10344

13. Rossi, F., Charlton, C. A., and Blau, H. M. Proc. Natl. Acad. Sci. U.S.A. 199794 8405-8410

14. Pelletier, J. N., Campbell-Valois, F. X., and Michnick, S. W. Proc. Natl. Acad. Sci. U.S.A. 199895 12141-12146 
a
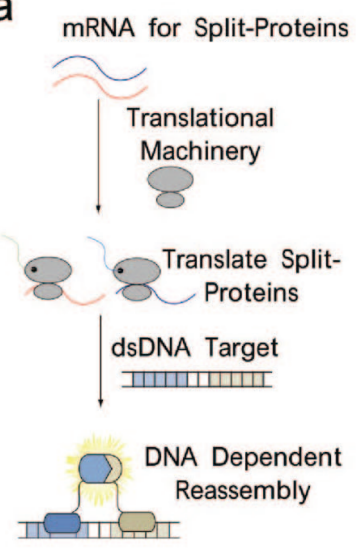

b

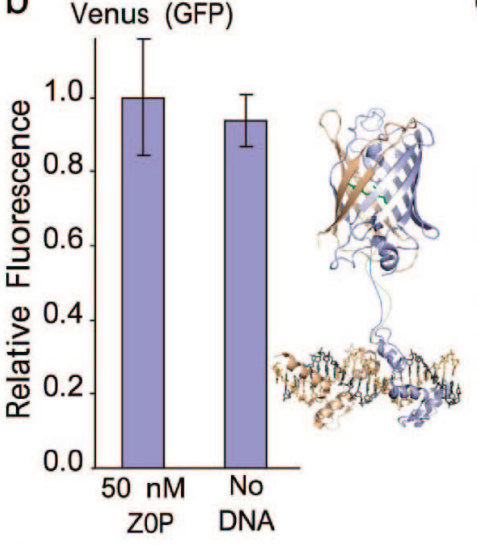

C $\beta$-Lactamase

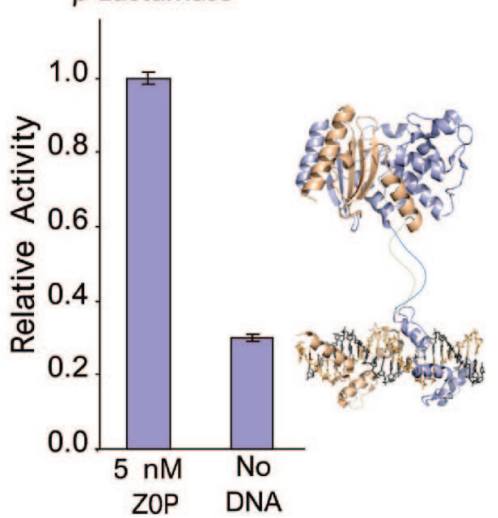

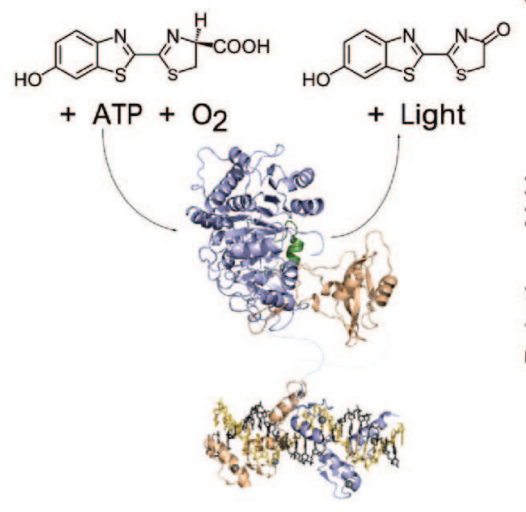

d

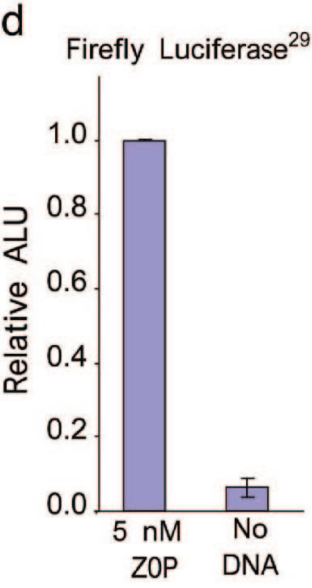

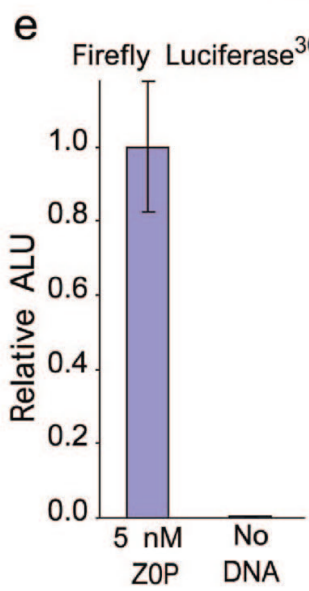

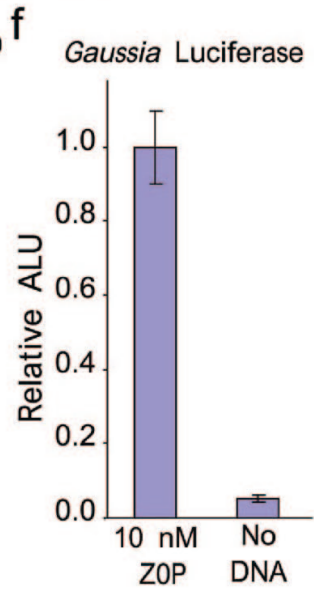

Figure 1. Cell-free detection utilizing split-proteins. (a) Cartoon representation of a split-protein system with zinc fingers tethered to split-proteins in the presence of a target dsDNA oligonucleotide. Different split-protein reporters tethered to sequence specific zinc fingers in the presence and absence of target dsDNA; (b) split-Venus (a GFP variant), (c) split- $\beta$-lactamase, (d) split-firefly luciferase as described by Luker et. al, $^{29}$ (e) splitfirefly luciferase as described by Paulmurugan et. al, ${ }^{30}$ and (f) split-Gaussia luciferase as described by Remy et. al. ${ }^{21}$

rent split-protein methods have certain limitations for interrogating protein-protein and protein-nucleic acid interactions and their inhibitors in a very rapid and high-throughput fashion. For example, current in vitro methods require extensive protein purification ${ }^{16,27}$ and also rely on proper folding of recombinant proteins, while in vivo methods require lengthy transfection and propagation of cellular cultures prior to analysis, both approaches being time intensive. ${ }^{25,} 28$ The current methods are also prone to problems arising from potential proteolysis of intracellularly expressed proteins and peptides as well as a lack of control over interfering coexpressed cellular factors as is also the case with yeast n-hybrid methods.

To provide a rapid and general method that circumvents many of the limitations discussed above, we hypothesized that fragmented reporter proteins fused to functional proteins could be rapidly generated directly from mRNA utilizing cell-free translation methodologies and immediately interrogated for biomolecular interaction-dependent signal generation. The use of split-proteins in cell-free translation takes advantage of fast protein synthesis rates, from 60 to $90 \mathrm{~min}$, and easy adaptation to homogeneous assays avoiding immobilization and washing protocols. Herein we demonstrate how this cell-free approach provides a general platform for rapidly detecting protein-protein, protein-small molecule, protein-DNA, protein-methylated DNA, and protein-RNA interactions starting from mRNA or directly from DNA corresponding to the desired interaction pair in less than $2 \mathrm{~h}$. Moreover, we demonstrate how this approach aids in determining the specificity of protein-nucleic acid interactions as well as in determining small-molecule antagonists of proteinprotein interactions, which are currently of much interest.
15. Galarneau, A., Primeau, M., Trudeau, L. E., and Michnick, S. W. Nat. Biotechnol. 200220 619-622

16. Ghosh, I., Hamilton, A. D., and Regan, L. J. Am. Chem. Soc. 2000122 5658-5659

17. MacDonald, M. L., Lamerdin, J., Owens, S., Keon, B. H., Bilter, G. K., Shang, Z., Huang, Z., Yu, H., Dias, J., Minami, T., Michnick, S. W., and Westwick, J. K. Nat. Chem. Biol. 20062 329-337

18. Hu, C. D., and Kerppola, T. K. Nat. Biotechnol. 200321 539-545

19. Jach, G., Pesch, M., Richter, K., Frings, S., and Uhrig, J. F. Nat. Methods 20063 597-600

20. Paulmurugan, R., Umezawa, Y., and Gambhir, S. S. Proc. Natl. Acad. Sci. U.S.A. 200299 15608-15613

21. Remy, I., and Michnick, S. W. Nat. Methods 20063 977-979

22. Ghosh, I., Stains, C. I., Ooi, A. T., and Segal, D. J. Mol. BioSyst. 2006 2551-560
23. Stains, C. I., Porter, J. R., Ooi, A. T., Segal, D. J., and Ghosh, I. J. Am. Chem. Soc. 2005127 10782-10783

24. Porter, J. R., Stains, C. I., Segal, D. J., and Ghosh, I. Anal. Chem. 2007 79 6702-6708

25. Ozawa, T., Natori, Y., Sato, M., and Umezawa, Y. Nat. Methods 2007 4 413-419

26. Rackham, O., and Brown, C. M. EMBO J. 200423 3346-3355

27. Ooi, A. T., Stains, C. I., Ghosh, I., and Segal, D. J. Biochemistry 2006 $453620-3625$

28. Remy, I., Campbell-Valois, F. X., and Michnick, S. W. Nat. Protoc. 20072 2120-2125

29. Luker, K. E., Smith, M. C. P., Luker, G. D., Gammon, S. T., PiwnicaWorms, H., and Piwnica-Worms, D. Proc. Natl. Acad. Sci. U.S.A. 2004101 12288-12293

30. Paulmurugan, R., and Gambhir, S. S. Anal. Chem. 200779 2346-2353 


\section{Results and Discussion}

Evaluation of Split-Protein Reporters for the Cell-Free Interrogation of Biomolecular Interactions. Initially, we evaluated the ability of our previously reported split-GFP23 and split- $\beta$-lactamase $\mathrm{e}^{24,27}$ systems appended to specific zinc fingers to reassemble in the presence of target DNA utilizing in vitro transcribed $\mathrm{mRNA}$ in a purified wheat germ extract translation system (Figure 1b,c). Signal from the DNA-dependent reassembled GFP ${ }^{23}$ was too low to observe over background using standard fluorescence measurements, while DNA-dependent $\beta$-lactamase activity ${ }^{27}$ yielded measurable but low signal-to-background ratios. Thus, we turned to recently reported in vivo split-luciferase systems which have the significant advantage of negligible background from the translation system due to the generation of a bioluminescent signal (Figure 1a). We chose to first examine the fragmented firefly luciferase (Fluc) reported by Luker et. $a l^{29}$ which, when appended to our zinc fingers, showed significant signal over background luminescence upon addition of target DNA (Figure 1d). This comprises the first demonstration of the bioluminescent readout of a specific nucleic acid sequence, and accordingly this split-luciferase system was chosen for further studies in cellfree systems. The very recently described split-Gaussia lucifer$a^{2} e^{21}$ and alternatively split-firefly luciferase complementation systems $^{29,} 30$ were also tethered to our zinc fingers and displayed extremely good signal over background bioluminescence (Figure 1e,f) in a DNA-dependent fashion and are currently being evaluated for their relative merits in a number of cell-free assays.

Detection of Protein-Protein and Protein-Nucleic Acid Interactions. To test the generality of the cell-free split-luciferase approach we chose to investigate seven well-characterized and widely studied biomolecular interactions (Figure 2): (a) the catalytic subunit of cAMP-dependent protein kinase (PKA) with its inhibitor PKI (PKA/PKI) $)^{31-33}$ and (b) the rapamycin-dependent interaction between the human FK506binding protein 12 (FKBP) and the FKBP12-rapamycin binding (FRB) domain of human mTOR (FKBP/FRB). ${ }^{34-36}$ Akin to the yeast three hybrid systems, ${ }^{37}$ we also investigated the ternary association of (c) two sequence-specific zinc fingers ${ }^{38}$ with a target DNA (Zif268/PBSII), (d) a zinc finger and methyl CpG-binding domain with a target CpG-methylated DNA (Zif268/MBD2), ${ }^{39-42}$ and finally (e) two RNA-specific pumilio domains ${ }^{43}$ with a target RNA (Pum1/Pum2). Additionally the widely utilized coiled-coil domains of the transcription factors Fos and Jun (Fos/Jun) ${ }^{44-46}$ and the interaction between hy-

31. Knighton, D. R., Zheng, J. H., Ten Eyck, L. F., Xuong, N. H., Taylor, S. S., and Sowadski, J. M. Science 1991253 414-420

32. Narayana, N., Cox, S., Shaltiel, S., Taylor, S. S., and Xuong, N. H. Biochemistry 199736 4438-4448

33. Taylor, S. S., Buechler, J. A., and Yonemoto, W. Annu. Rev. Biochem. 1990 59 971-1005

34. Chen, J., Zheng, X. F., Brown, E. J., and Schreiber, S. L. Proc. Natl. Acad. Sci. U.S.A. 199592 4947-4951

35. Brown, E. J., Albers, M. W., Shin, T. B., Ichikawa, K., Keith, C. T., Lane, W. S., and Schreiber, S. L. Nature 1994369 756-758

36. Vanduyne, G. D., Standaert, R. F., Schreiber, S. L., and Clardy, J. J. Am. Chem. Soc. 1991113 7433-7434

37. Vidal, M., and Legrain, P. Nucleic Acids Res. 199927 919-929

38. Wolfe, S. A., Nekludova, L., and Pabo, C. O. Annu. Rev. Biophys. Biomol. Struct. 200029 183-212

39. Stains, C. I., Furman, J. L., Segal, D. J., and Ghosh, I. J. Am. Chem. Soc. 2006128 9761-9765

40. Esteller, M., Corn, P. G., Baylin, S. B., and Herman, J. G. Cancer Res. $2001613225-3229$ poxia inducible factor- $1 \mathrm{a}$ (HIF-1a) and the $\mathrm{CH} 1$ domain of the transcriptional coactivator p300 (HIF-1a/p300) ${ }^{47,} 48$ were also tested (Supporting Information, Figure S1). The overall sensitivity (signal/background) of these systems (Figure 2a-e) was excellent and varied from 22 to 1800 -fold, while the total assay time from translation to analysis was less than $2 \mathrm{~h}$.

We also investigated whether it was possible to directly couple transcription and translation in a cell-free lysate system, which may eventually eliminate the need for the separate in vitro transcription step that we are currently employing. (Figure 3). These experiments were likewise successful for both DNA and small-molecule dependent interactions (Figure $3 a, b)$. In addition to using purified lysate, we further interrogated whether we could detect the above interactions using a system composed entirely of purified translational components ${ }^{49,50}$ (Figure 3c,e), the so-called "PURE System," thus demonstrating that reconstituted transcription and translation machinery is sufficient for detecting biomolecular interactions. This set of experiments clearly validates that a cell-free splitluciferase assay format allows for the rapid, sensitive, and direct detection of protein-protein, protein-small molecule, protein-DNA, protein-methylated DNA, and protein-RNA interactions starting from either mRNA or directly from DNA corresponding to the desired interaction pair. Having established that our methodology provides robust signal for a wide variety of biomolecular interactions we turned to investigating whether this system is amenable to reporting upon inhibitors of protein-nucleic acid and protein-protein interactions.

Detecting Antagonists of Protein-Nucleic Acid Interactions. In order to detect antagonists of protein-protein or protein-nucleic acid interactions, we first needed to demonstrate the thermodynamic reversibility of the ternary complex consisting of reassembled firefly luciferase fragments tethered to two zinc fingers (PBSII and Zif268) and target DNA (Figure 4a). Toward this goal, translations using mRNA encoding PBSII-NFluc and CFluc-Zif268 were initiated in the presence of the target oligonucleotide (Zif268-0-PBSII). Post DNA dependent firefly luciferase reassembly, a hairpin DNA (hpDNA-Zif268), which is a competitor for only Zif268 binding, was added at increasing concentrations followed by equilibration for $30 \mathrm{~min}$. A concentration dependent decrease in luminescence was observed, clearly demonstrating that the ternary complex of firefly luciferase and dsDNA was reversible and could be inhibited by addition of the dominant-negative (hpDNA-Zif268) oligonucleotide (Figure 4b, TGG containing hpDNA). The generality of utilizing the cell-free system for probing protein-nucleic acid inhibition was further demonstrated with translations containing mRNA

41. Fraga, M. F., Ballestar, E., Montoya, G., Taysavang, P., Wade, P. A., and Esteller, M. Nucleic Acids Res. 200331 1765-

42. Ohki, I., Shimotake, N., Fujita, N., Jee, J. G., Ikegami, T., Nakao, M., and Shirakawa, M. Cell 2001105 487-497

43. Cheong, C. G., and Hall, T. M. Proc. Natl. Acad. Sci. U.S.A. 2006103 13635-

44. O'Shea, E. K., Rutkowski, R., and Kim, P. S. Cell 199268699

45. O'Shea, E. K., Rutkowski, R., Stafford, W. F., and Kim, P. S. Science 1989245646

46. Meyer, S. C., Shomin, C. D., Gaj, T., and Ghosh, I. J. Am. Chem. Soc. $200712913812-13813$

47. Freedman, S. J., Sun, Z. Y., Poy, F., Kung, A. L., Livingston, D. M., Wagner, G., and Eck, M. J. Proc. Natl. Acad. Sci. U.S.A. 200299 5367-5372

48. Kung, A. L. et al. Cancer Cell 20046 33-43 (see Supporting Information).

49. Shimizu, Y., Inoue, A., Tomari, Y., Suzuki, T., Yokogawa, T., Nishikawa, K., and Ueda, T. Nat. Biotechnol. 2001 19 751-755

50. Shimizu, Y., Kanamori, T., and Ueda, T. Methods 200536 299-304 
a PKI-NFluc CFluc-PKA

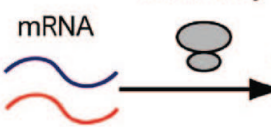

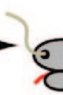

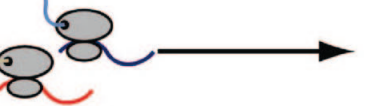

b FRB-NFIuc CFluc-FKBP

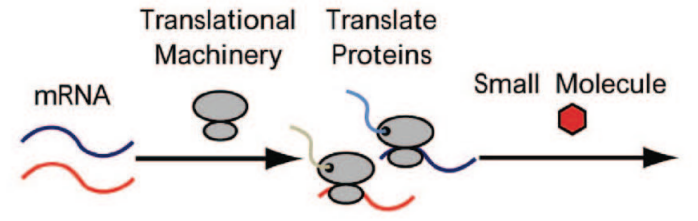

C

PBSII-NFluc CFluc-Zif268

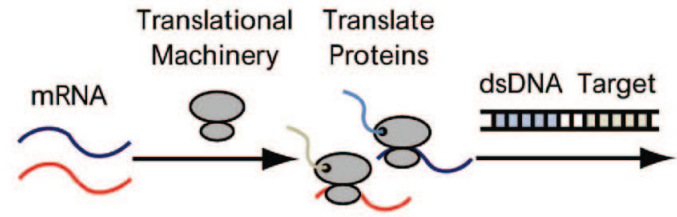

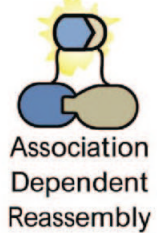

Reassembly

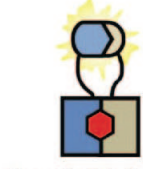

Small Molecule Dependent Reassembly

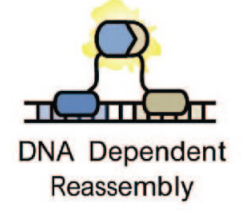

Reassembly
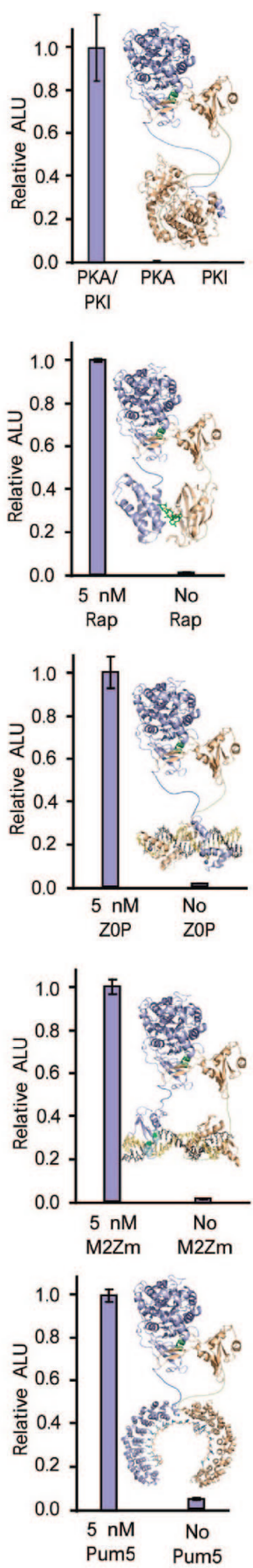

Figure 2. Cell-free detection of a wide variety of biomolecular interactions utilizing split-firefly luciferase starting from mRNA. Detection of (a) the protein-protein interaction between PKI-NFluc and CFluc-PKA; (b) the rapamycin-induced interaction between FRB-NFluc and CFluc-FKBP; (c) the protein-DNA interaction between PBSII-NFluc, CFluc-Zif268, and a target dsDNA oligonucleotide; (d) the methylation-dependent proteinDNA interaction between MBD2-NFluc, CFluc-Zif268, and a target methylated CpG dsDNA oligonucleotide; and (e) the protein-RNA interaction between Pum2-NFluc, CFluc-Pum1, and a target RNA oligonucleotide.

encoding Pum2-NFluc and CFluc-Pum1 in the presence of target RNA. As earlier, a concentration-dependent decrease in luminescence was observed only upon the addition of increasing amounts of a competitor half-site RNA target that is known to selectively bind one of the pumilio domains ${ }^{43}$ (Figure 4e). Building on these results, we envisioned that our split-luciferasebased cell-free system could be readily utilized to analyze the relative target site specificity of nucleic acid binding proteins through competitive binding experiments.
Identification of Protein-DNA Target-Site Specificity. A number of methods have been developed to interrogate the relative affinity of DNA-binding proteins for their target site, including traditional EMSAs and more recently DNA microarrays. ${ }^{51,52}$ Although powerful, these techniques require the use

51. Berger, M. F., Philippakis, A. A., Qureshi, A. M., He, F. S., Estep, P. W., and Bulyk, M. L. Nat. Biotechnol. 200624 1429-1435

52. Bulyk, M. L., Huang, X. H., Choo, Y., and Church, G. M. Proc. Natl. Acad. Sci. U.S.A. 200198 7158-7163 

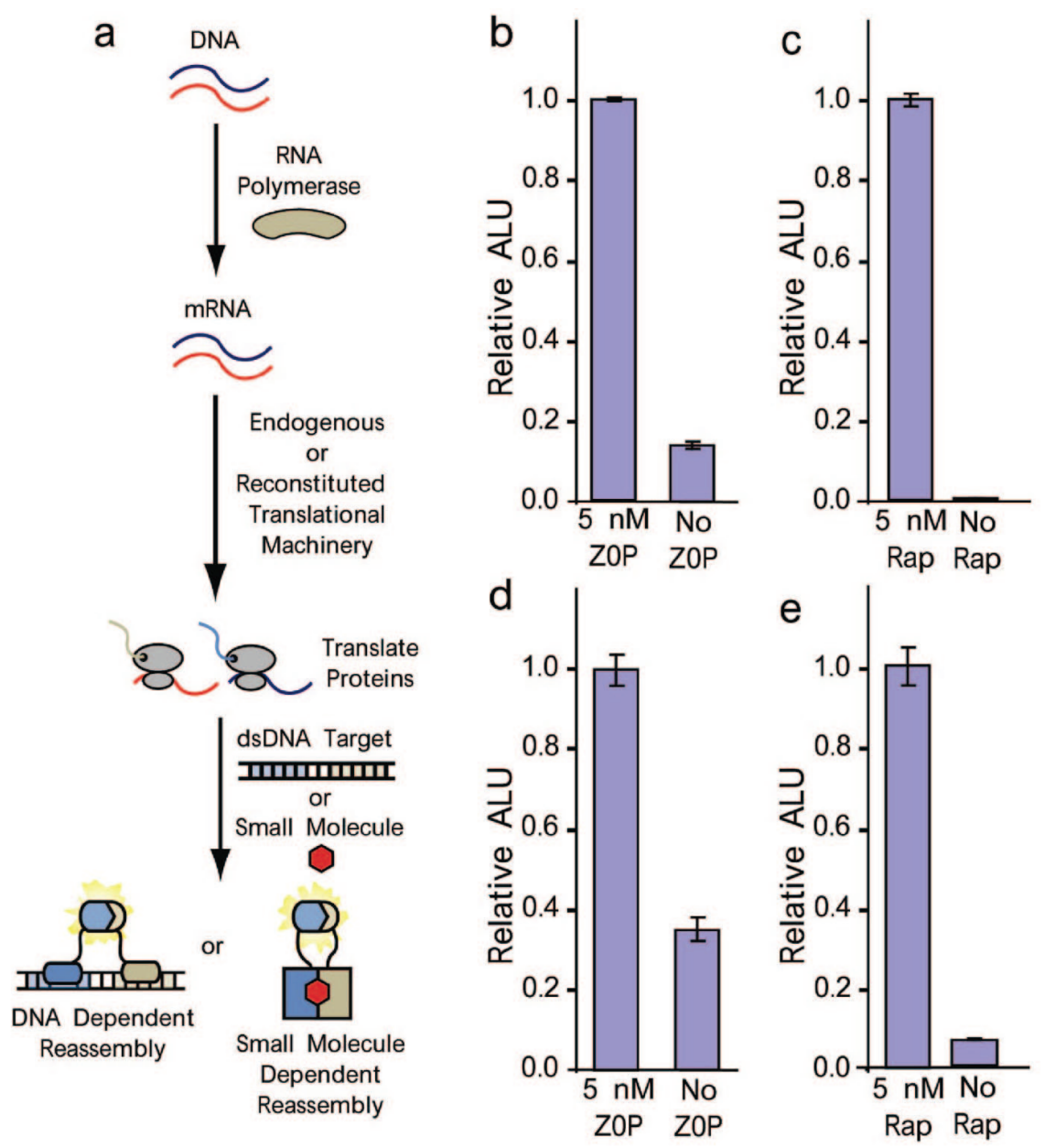

Figure 3. Cell-free detection of biomolecular interactions with split-luciferase starting from DNA utilizing a coupled transcription and translation cell-free lysate system: (a) the protein-DNA interaction between PBSII-NFluc, CFluc-Zif268, and $5 \mathrm{nM}$ target dsDNA oligonucleotides and (b) the rapamycin-induced $(5 \mathrm{nM})$ interaction between FRB-NFluc and CFluc-FKBP. Detection of biomolecular interactions utilizing purified DNA in the PURESYSTEM classic II system consisting of completely purified transcriptional and translational components: (c) the protein-DNA interaction between PBSII-NFluc, CFluc-Zif268, and 5nM target dsDNA oligonucleotide and (d) the rapamycin-induced (5 nM) interaction between FRBNFluc and CFluc-FKBP.

of purified components, specialized equipment, or radioactive materials. Having established that ternary zinc finger-DNA complexes can be disrupted by a competitor oligonucleotide added in trans, we next attempted to correlate the known binding affinities of Zif268 for single-nucleotide changes in its binding site to $\mathrm{IC}_{50}$ values obtained from our cell-free firefly luciferase approach in a 96-well format. Separate translation reactions containing both PBSII-NFluc and CFluc-Zif268 mRNA in the presence of the dsDNA target oligonucleotide, Zif268-0-PBSII, were initiated. Duplicate experiments were allowed to translate and assemble for $90 \mathrm{~min}$, forming ternary complexes, followed by the addition of increasing concentrations of a competitor hpDNA, containing one of four different Zif268 binding sites having either $A, T, C$, or $G$ at the central position. In each case a competitor hpDNA concentration-dependent decrease in luminescence was observed (Figure $4 \mathrm{~b}$ ) within $30 \mathrm{~min}$. $\mathrm{IC}_{50}$ values for each competitor hpDNA (Figure 4c) were shown to correlate extremely well $\left(R^{2}=0.996\right)$ (Figure $4 \mathrm{~d}$ ) with previously reported relative affinities of these target sites. ${ }^{52}$ These results serve to validate the application of the split-luciferase cell-free system for the determination of relative binding affinities of nucleic acid-binding proteins for their target sites and more generally in studying inhibitors of protein-nucleic acid interactions. Thus this cell-free system provides an attractive alternative to current methods for interrogating protein-nucleic acid binding specifities as it can be performed in a simple, rapid, highthroughput, and homogeneous format without having to purify or refold the protein(s) of interest.

Detection of Small-Molecule and Peptide Modulators of Protein-Protein Interactions. Having demonstrated the ability to measure antagonists of protein-nucleic acid interactions, we next sought to interrogate the ability of cell-free firefly luciferase reassembly to report on antagonists and agonists of proteinprotein interactions. As a first test of small-molecule modulation of split-luciferase activity we chose the well-characterized rapamycin-dependent interaction between the human FK506binding protein 12 (FKBP) and the FKBP12-rapamycin binding (FRB) domain of human mTOR (residues 2024-2113) ${ }^{34}$ which has been a standard test for several split-protein reporter systems. ${ }^{21,29,30}$ A rapamycin concentration-dependent increase in luminescence was observed as expected from the cell-free translations of the split-reporters (Figure 5a). ${ }^{29}$

As our first test for antagonism of protein-protein interactions, we chose the well-characterized interaction between the catalytic subunit of cAMP-dependent protein kinase (PKA) with its inhibitor PKI (residues 5-24). ${ }^{31}$ Initial experiments had demonstrated that the fusion proteins PKI-NFluc and CFlucPKA could be translated in vitro from mRNA and their associa- 

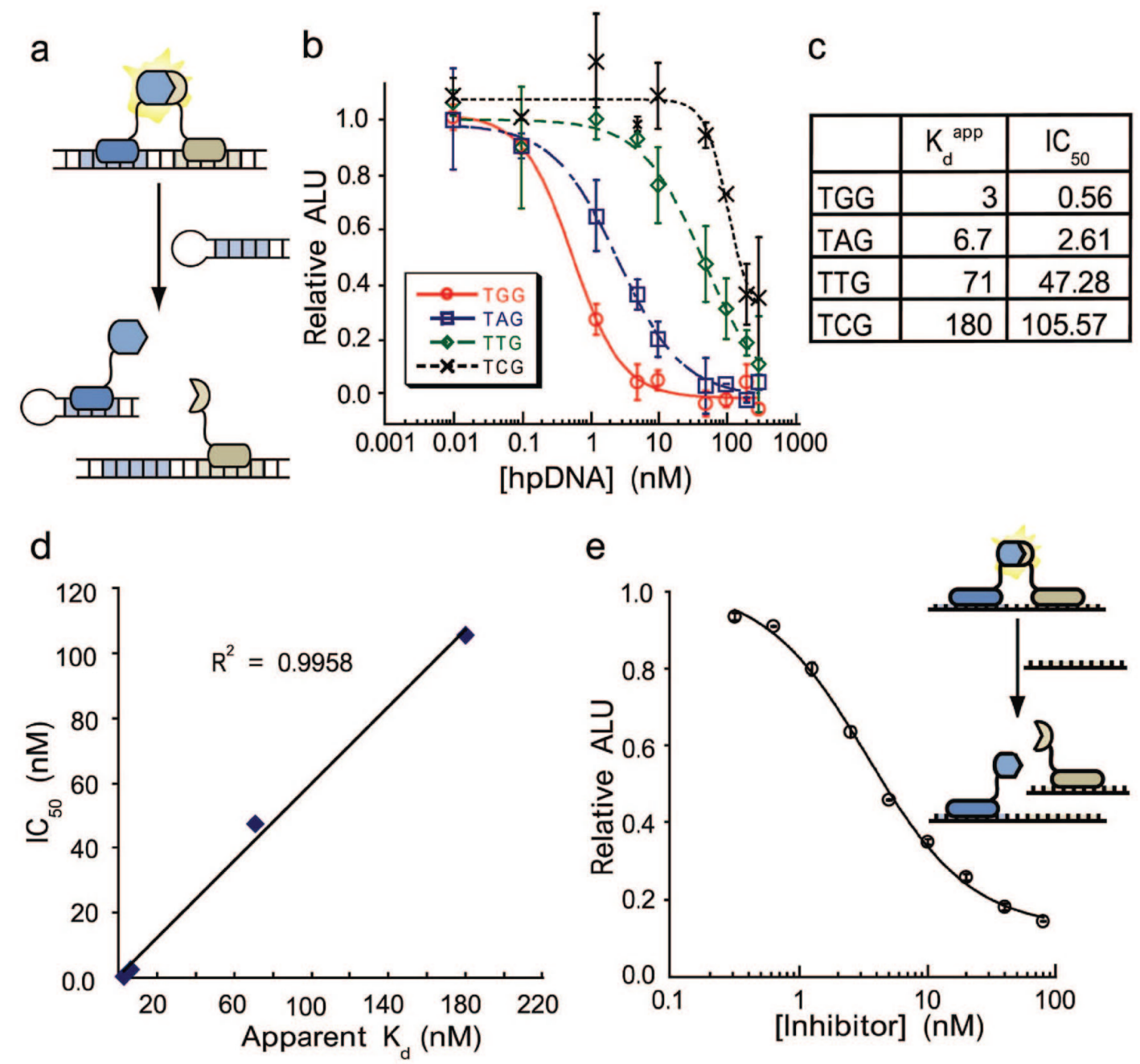

Figure 4. Interrogation of protein-nucleic acid interactions utilizing a split-firefly luciferase cell-free assay. (a) Cartoon showing the dissociation of the reassembled dsDNA-firefly luciferase ternary complex by the addition of a competitor hairpin DNA containing one of the two zinc finger binding sites. (b) Dissociation of the reassembled PBSII-NFluc, CFluc-Zif268, and dsDNA ternary complex by the addition of Zif268 hairpin DNA targets containing TGG (wild type, middle finger), TAG, TTG, and TCG triplet base pairs. (c) Previously reported relative affinities ${ }^{49}$ of target oligonucleotides with Zif268 with $\mathrm{IC}_{50}$ values derived from the cell-free firefly luciferase reassembly assay and their correlation (d). (e) Dissociation of the Pum2-NFluc, CFluc-Pum1, and RNA ternary complex by the addition of an RNA target containing a Pum1 binding site.
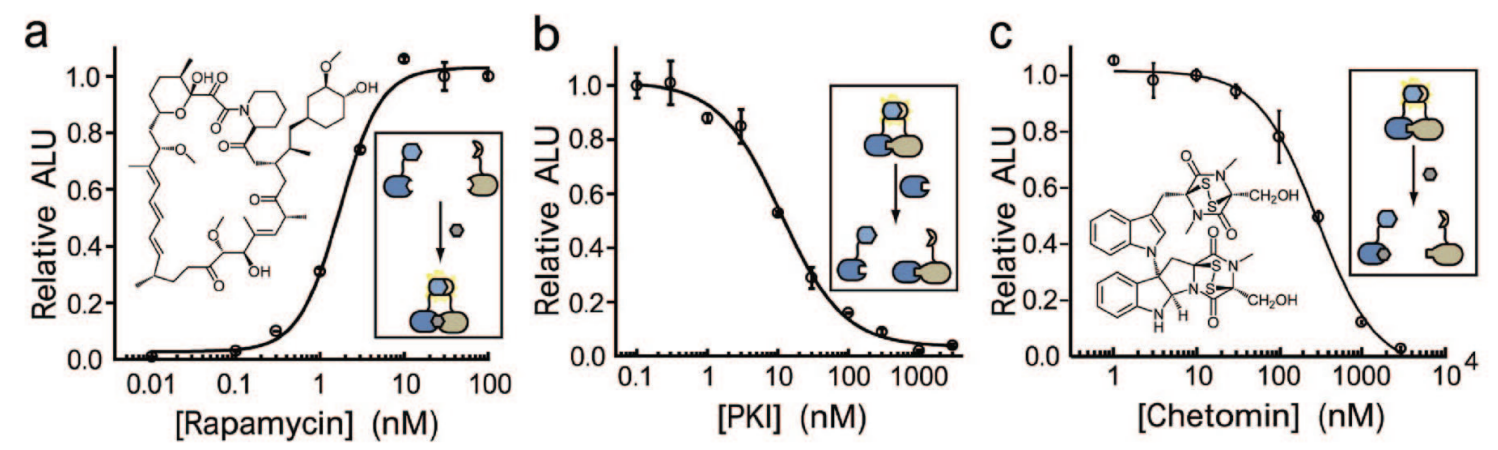

Figure 5. Interrogation of small-molecule and peptide modulators of protein-protein interactions utilizing the split-firefly luciferase cell-free assay. (a) Concentration-dependent association of FRB-NFluc and CFluc-FKBP mediated by rapamycin (inset). (b) Concentration-dependent dissociation of the PKI-NFluc/CFluc-PKA complex by PKI peptide. (c) Concentration-dependent dissociation of the reassembled p300-NFluc/CFlucHif1a complex by chetomin (inset).

tion monitored via luminescence (Figure 2a). Knowing that the reassembly of fragmented firefly luciferase is dependent upon PKA/PKI complex formation, the inhibition of this interaction was interrogated by the addition of increasing concentrations of a PKI peptide ${ }^{46}$ yielding an observed $\mathrm{IC}_{50}$ value of 11 $\mathrm{nM}$ (Figure $5 \mathrm{~b}$ ). As a further example of the generality of this cell-free format, we interrogated the inhibition of an emerging anticancer target, specifically the interaction between hypoxia inducible factor-1a (HIF-1a) and the CH1 domain of the transcriptional coactivator p300. ${ }^{53}$ Initial experiments (Supporting Information, Figure S1) demonstrated that the fusion proteins p300-NFluc and CFluc-HIF-1a could be translated in vitro 
a

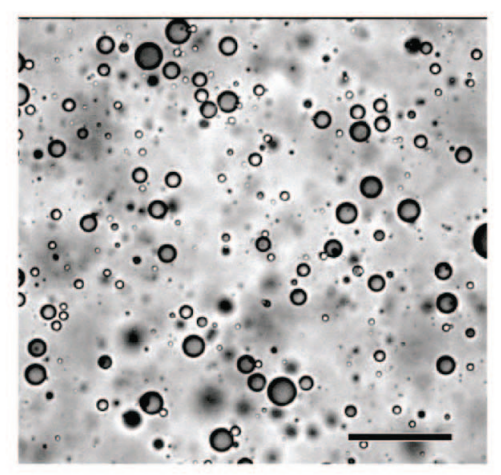

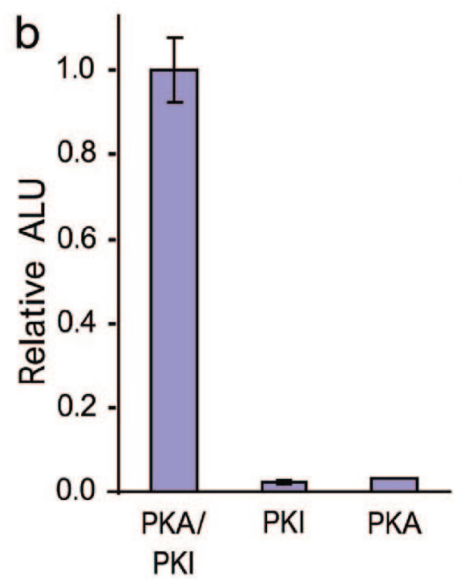

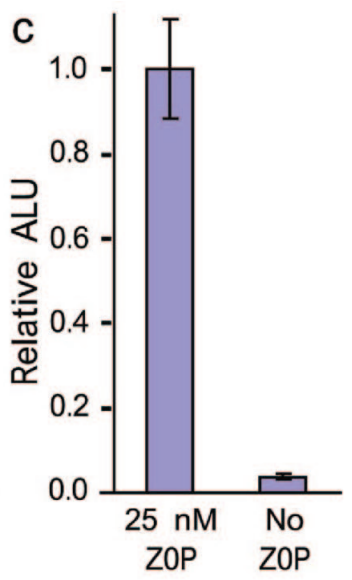

Figure 6. Protein-protein and protein-DNA interactions in artificial cells interrogated by split-firefly luciferase-dependent bioluminescence. (a) White light microscope image of a water-in-oil emulsion containing a PKI-NFluc/CFluc-PKA translation in wheat germ extract. Scale bar is equal to $75 \mu \mathrm{m}$. (b) Protein-protein association (PKI-NFluc/CFluc-PKA)-dependent split-luciferase reassembly and bioluminescence within water-in-oil emulsion. (c) Protein-DNA interaction-dependent firefly luciferase reassembly within water-in-oil emulsion.

from mRNA and their association monitored via luminescence. Recently, the small molecule chetomin has been identified as a first-in-class inhibitor of the interaction between HIF-1a and p300. ${ }^{48}$ To evaluate if our method could aid in the identification of small-molecule inhibitors, mRNA encoding p300-NFluc and CFluc-HIF-1a fusion proteins were translated followed by the addition of increasing concentrations of the small molecule chetomin postreassembly. Luminescence measurements following chetomin incubation revealed a concentration dependent decrease in signal and yielded an $\mathrm{IC}_{50}$ value of $290 \mathrm{nM}$ (Figure 5c). Importantly, control experiments with excess chetomin or PKI-peptide showed no effect on signal generation in the zinc finger/DNA cell-free assay (Supporting Information, Figure S2), which verified that the loss in signal was dependent upon the disruption of specific protein-protein interactions rather than off-target effects such as inhibition of luciferase activity. Thus, these three systems demonstrate that both peptide and small-molecule modulators of protein-protein interactions can be rapidly evaluated in the cell-free split-luciferase system without the need for transfection and cell-culture (current yeast n-hybrids and PCA methods), protein purification and selective fluorophore labeling (FP), or immobilization on solid surfaces (SPR and ELISA).

Application to Artificial Cell Systems. In addition to monitoring protein-protein and protein-nucleic acid interactions, the cell-free methodology described here could potentially be used for the selection of protein-protein and protein-nucleic acid interactions. Elegant experiments by Tawfik and Griffiths have recently established that water-in-oil emulsions of in vitro translation reactions can function as so-called artificial or "man-made" cells, which have been utilized for linking genotype with phenotype in protein evolution experiments. ${ }^{54,} 55$ Toward demonstrating that our cell-free split luciferase assay is compatible with in vitro compartmentalization, translations containing mRNA encoding PKI-NFluc and CFluc-PKA, or PBSII-NFluc, CFluc-Zif268 and target DNA were performed in wheat germ extract encapsulated in water-in-oil emulsions (Figure 6a), followed by luminescence analysis (Figure 6b,c). This set of experiments clearly demonstrates that the cellfree split-firefly luciferase system has the potential for being adapted in screens for protein-protein and protein-nucleic acid interactions in artificial cell-based methodologies and may also find applications in studying proteins incorporating unnatural amino acids where significantly greater control over translational machinery components is often desirable. ${ }^{56-60}$

\section{Conclusion}

Numerous in vitro and in vivo methods are being developed to interrogate the interactions between proteins and nucleic acids, including strategies utilizing the reassembly of split-protein reporters. Although powerful, current cell-based and in vitro strategies depend on a number of cumbersome and timeconsuming steps including transfection, cell culture, purification, washing steps, and/or covalent modification, yielding overall experimental times in excess of 12-48 h when starting from appropriate clones. Herein we have described a general platform for interrogating biomolecular interactions in homogeneous assays based on cell-free split-protein systems within $2 \mathrm{~h}$. This cell-free assay is capable of utilizing a variety of splitprotein reporters providing both fluorescent ( $\beta$-lactamase) and bioluminescent (luciferase) signal outputs. One drawback of the current method as also found in ELISA and in vivo approaches is that only relative affinities and $\mathrm{IC}_{50}$ values can be determined, unlike with methods such as FP and SPR. However, the speed and ease of implementation of this cell-free approach, which does not require cell culture, protein purification, or chemical derivatization, can be used to rapidly address biological and chemical questions with appropriate controls, as we have demonstrated with either dominant negative inhibition or a known small-molecule ligand.
53. Kung, A. L., Wang, S., Klco, J. M., Kaelin, W. G., and Livingston, D. M. Nat. Med. $200061335-1340$

54. Tawfik, D. S., and Griffiths, A. D. Nat. Biotechnol. 199816 652-

55. Miller, O. J., Bernath, K., Agresti, J. J., Amitai, G., Kelly, B. T., Mastrobattista, E., Taly, V., Magdassi, S., Tawfik, D. S., and Griffiths, A. D. Nat. Methods 20063 561-570

56. Forster, A. C., Tan, Z. P., Nalam, M. N. L., Lin, H. N., Qu, H., Cornish, V. W., and Blacklow, S. C. Proc. Natl. Acad. Sci. U.S.A. 2003

\section{$1006353-6357$}

57. Mendel, D., Cornish, V. W., and Schultz, P. G. Annu. Rev. Biophys. Biomol. Struct. 199524 435-462

58. Rackham, O., and Chin, J. W. Nat. Chem. Biol. 20051 159-166

59. Seebeck, F. P., and Szostak, J. W. J. Am. Chem. Soc. 2006128 7150-7151

60. Goto, Y., Ohta, A., Sako, Y., Yamagishi, Y., Murakami, H., and Suga, H. ACS Chem. Biol. 20083 120-129 
Our experiments demonstrate the ability to detect a wide variety of protein-protein interactions, including the wellstudied heterodimerization of the leucine zippers Fos and Jun, the interaction between the protein kinase PKA and its inhibitor PKI, and the small-molecule-dependent interaction between FKBP and FRB. Additionally, we provide the first example of a rapid method for interrogating the interaction between HIF-1a and p300, an emerging protein-protein target implicated in cancer progression. Furthermore, we detail the first examples of sensitive split-luciferase-mediated detection of a wide range of protein-nucleic acid interactions, including zinc finger domains with specific dsDNA, a methyl CpG-binding domain with specific methylated DNA, and RNA binding pumilio domains with target RNA. We have also demonstrated that this methodology can be utilized to interrogate the relative binding affinities of nucleic acid binding proteins for their target sites and the evaluation of smallmolecule and peptide modulators of protein-protein interactions. In addition to using purified lysate and wheat germ extract, we have demonstrated the detection of protein-protein and protein-nucleic acid interactions using a system composed entirely of purified components that minimizes nonspecific interactions from cellular components and allows control over the translational machinery. This may find utility in numerous applications involving unnatural amino acid incorporation. ${ }^{56-60}$ Finally, we have demonstrated that the splitprotein reporters are functional in water-in-oil emulsions, providing artificial cell systems for studying protein-protein and protein-nucleic acid interactions that can potentially be utilized in screening methodologies. ${ }^{54}$

We envision that this cell-free format could potentially be used in a wide-variety of applications that include screening of DNA or RNA target sites for nucleic acid binding proteins and the determination of target site preference. More importantly perhaps, this approach can be used for screening small molecules, nucleic acids, peptides, or proteins for inhibition of specific protein-protein or protein-nucleic acid interactions. ${ }^{1,2}$ Moreover, since split-protein approaches have been widely utilized in a cellular context, the initial hits from the rapid cell-free system can be rapidly tested in a cellular context. ${ }^{10,20}$ Thus, we anticipate that this rapid, sensitive, and homogeneous assay system will be widely utilized for interrogating user-defined natural and unnatural biomolecular interactions and for evaluating agonists and antagonists of these interactions.

\section{Materials and Methods}

General Materials. All materials were obtained from Sigma-Aldrich unless otherwise noted. $\mathrm{ZnCl}_{2}$ was obtained from EM Sciences. Restriction enzymes were obtained from NEB and in vitro translational products from Promega. Oligonucleotide primers and targets were from IDT.

Plasmid Construction and mRNA Production. The fusion protein constructs used in this study are shown in Supporting Information, Table S1. DNA coding for N-terminal and C-terminal reporter protein fragments (GFP, $\beta$-lactamase, and three luciferases) were generated by PCR with appropriate primers and subsequently cloned into either the pETDuet-1 vector (Novagen) or the pMAL-c2x vector (NEB) using standard techniques with verification by dideoxyoligonucleotide sequencing. Fragments encoding the nucleic acid-binding or associating proteins used in this study were generated by PCR starting from specific plasmids. The fusion protein constructs were generated using standard cloning techniques and verified by dideoxyoligonucleotide sequencing. The mRNA necessary for cell-free assays was generated as follows: PCR fragments corresponding to the desired fusion constructs were generated using a forward primer containing a T7 RNA polymerase promoter and a Kozak sequence and a reverse primer containing a $3^{\prime}$ hairpin loop. The purified PCR products were subsequently used as templates for in vitro transcription using the RiboMAX Large Scale RNA Production System-T7 (Promega) following the manufacturer's protocols.

Target DNA Preparation. All nucleic acid targets were obtained from IDT. A dsDNA target containing a zero base pair separation between the Zif268 and PBSII zinc finger sites (ZOP) was annealed as previously described. ${ }^{23}$ Hairpin DNA targets were annealed in $1 \times$ Bam HI buffer by heating at $95{ }^{\circ} \mathrm{C}$ for 7 min followed immediately by cooling on ice.

Reassembly of the GFP Variant Venus. Duplicate $150 \mu \mathrm{L}$ translations were carried out in Wheat Germ Plus extract (Promega) according to the manufacturer's protocol using 4 pmol of each mRNA encoding for NVenus(residues 1-157)-Zif268 and PBSII-CVenus(residues 158-238), $10 \mu \mathrm{M} \mathrm{ZnCl}$, $0.5 \mu \mathrm{L}$ of RNasin Plus (Promega), and either $50 \mathrm{nM}$ Z0P target DNA or no DNA. Translations were incubated at $25^{\circ} \mathrm{C}$ for $2 \mathrm{~h}$ (after which no fluorescence was observed) followed by interrogation for fluorescence after a $20 \mathrm{~h}$ incubation at $4{ }^{\circ} \mathrm{C}$. Fluorescence spectra were acquired by exciting at $515 \mathrm{~nm}$ and monitoring emission at $528 \mathrm{~nm}$.

Reassembly of Split $\beta$-Lactamase-Zinc Finger Fusions. Four duplicate $25 \mu \mathrm{L}$ translations were carried out in Wheat Germ Plus extract (Promega) according to the manufacturer's protocol using $0.5 \mathrm{pmol}$ of each mRNA encoding for N $\beta$ Lac(residues 26-196)-Zif268 and PBSII-C $\beta$ Lac(residues 198-290), $10 \mu \mathrm{M} \mathrm{ZnCl}_{2}, 0.5 \mu \mathrm{L}$ of RNasin Plus (Promega), and either $20 \mathrm{nM}$ Z0P target DNA or no DNA. Translations were incubated at $25^{\circ} \mathrm{C}$ for $2 \mathrm{~h}$ and assayed by combining $25 \mu \mathrm{L}$ of translation solution to $75 \mu \mathrm{L}$ of PBS buffer containing a final concentration of $10 \mu \mathrm{M}$ Fluorocilin Green soluble $\beta$-lactamase substrate (Invitrogen). The final concentration of DNA in the assay was $5 \mathrm{nM}$. The rate of Fluorocillin Green hydrolysis was determined by exciting at $495 \mathrm{~nm}$ and monitoring emission at $525 \mathrm{~nm}$ with a $515 \mathrm{~nm}$ emission cutoff using a Spectra Max Gemini plate reader. Emission was read every $30 \mathrm{~s}$ for $10 \mathrm{~min}$.

Reassembly of Split-Firefly Luciferase. Duplicate 25 $\mu \mathrm{L}$ translations were carried out in Flexi-Rabbit Reticulocyte Lysate (Promega) according to the manufacturer's protocol using 2 pmol of each mRNA encoding for either PBSIINFluc(residues 2-416) and CFluc(residues 398-550)-Zif268 or NFluc(residues 2-398)-Zif268 and PBSII-CFluc(residues 394-550), $10 \mu \mathrm{M} \mathrm{ZnCl}_{2}, 0.5 \mu \mathrm{L}$ of RNasin Plus (Promega), and either $25 \mathrm{nM}$ Z0P target DNA or no DNA. Translations were incubated at $30{ }^{\circ} \mathrm{C}$ for $90 \mathrm{~min}$ and assayed by combining 20 $\mu \mathrm{L}$ of translation solution with $80 \mu \mathrm{L}$ of Steady-Glo Luciferase Assay System (Promega). The final concentration of DNA in the assay was $5 \mathrm{nM}$. Light emission was monitored 1 min after Steady-Glo addition using a Turner TD-20e luminometer with a $3 \mathrm{~s}$ delay and a $10 \mathrm{~s}$ integration time.

Reassembly of Gaussia Luciferase. Duplicate $25 \mu \mathrm{L}$ translations were carried out in Flexi-Rabbit Reticulocyte Lysate (Promega) according to the manufacturer's protocol using 2 pmol of each mRNA encoding for NGluc(residues 17-109)Zif268 and PBSII-CGluc(residues 110-185), $1 \mu \mathrm{M} \mathrm{ZnCl}_{2}, 0.5 \mu \mathrm{L}$ of RNasin Plus (Promega), and either $50 \mathrm{nM}$ Z0P target DNA or no DNA. Translations were incubated at $30{ }^{\circ} \mathrm{C}$ for $90 \mathrm{~min}$ and assayed by combining $20 \mu \mathrm{L}$ of translation solution with 
$80 \mu \mathrm{L}$ of PBS buffer containing a final concentration of $20 \mu \mathrm{M}$ coelenterazine. The final concentration of DNA in the assay was $5 \mathrm{nM}$. Light emission was monitored 10 min after coelenterazine addition using a Turner TD-20e luminometer with a 3 $\mathrm{s}$ delay and a $10 \mathrm{~s}$ integration time.

Protein-Protein Interaction-Dependent Reassembly of Firefly Luciferase. Duplicate $25 \mu \mathrm{L}$ translations were carried out in Flexi-Rabbit Reticulocyte Lysate (Promega) according to the manufacturer's protocol using 2 pmol of each mRNA encoding the fusion proteins being analyzed, and $0.5 \mu \mathrm{L}$ of RNasin Plus (Promega). Translations were incubated at $30{ }^{\circ} \mathrm{C}$ for $90 \mathrm{~min}$ and assayed by combining $20 \mu \mathrm{L}$ of translation solution to $80 \mu \mathrm{L}$ of Steady-Glo Luciferase Assay System (Promega). For the rapamycin-induced interaction between FRB and FKBP either $5 \mathrm{nM}$ rapamycin or control (DMSO) was added after translation followed by a 30 min incubation at room temperature. Light emission was monitored 1 min after Steady-Glo addition using a Turner TD-20e luminometer with a 3 s delay and a 10 s integration time.

Reassembly of Split-Firefly Luciferase in a Coupled Transcription/Translation System. Coupled transcription/ translation reactions were carried out in TNT T7 Coupled Rabbit Reticulocyte Lysate (Promega) according to the manufacturer's protocol. Coupled reactions using split-firefly luciferase-zinc finger fusions contained 0.5 pmols of each DNA encoding PBSII-NFluc and CFluc-Zif268, $10 \mu \mathrm{M} \mathrm{ZnCl}_{2}, 1 \mu \mathrm{L}$ of RNasin Plus (Promega), and either $100 \mathrm{nM}$ Z0P target DNA or no DNA in a total of $25 \mu \mathrm{L}$. Coupled reactions using split-firefly luciferase-FKBP and FRBP fusions contained 0.5 pmol of DNA encoding FRB-NFluc and CFluc-FKBP, and $1 \mu \mathrm{L}$ of RNasin Plus (Promega) in a total of $25 \mu \mathrm{L}$. Solutions were incubated at $30^{\circ} \mathrm{C}$ for $90 \mathrm{~min}$. Reactions were diluted at a 1:4 ratio into PBS buffer containing 1\% BSA (1\% BSA and either $25 \mathrm{nM}$ rapamycin or DMSO in the case of FRB/FKBP) and equilibrated at room temperature for $30 \mathrm{~min}$. Samples were assayed for luciferase activity by combining $20 \mu \mathrm{L}$ of translation solution with $80 \mu \mathrm{L}$ of Steady-Glo Luciferase Assay System (Promega). Luminescence readings were taken on a Turner TD20e luminometer using a 3 s delay and a 10 $\mathrm{s}$ integration; the average of replicate experiments is shown. The final concentration of Z0P or rapamycin in the assay was $5 \mathrm{nM}$.

Reassembly of Split-Firefly Luciferase in a Purified Transcription/Translation System. Coupled transcription/ translation reactions were carried out using the PURESYSTEM classic II system (Post Genome Inst. Co. Ltd.) according to the manufacturer's protocol. Coupled reactions using split-firefly luciferase-zinc finger fusions contained 0.5 pmols of each DNA encoding PBSII-NFluc and CFluc-Zif268, $10 \mu \mathrm{M}$ $\mathrm{ZnCl}_{2}, 1 \mu \mathrm{L}$ of RNasin Plus (Promega), and either $100 \mathrm{nM}$ Z0P target DNA or no DNA in a total of $25 \mu \mathrm{L}$. Coupled reactions using split-firefly luciferase-FKBP and FRBP fusions contained 0.5 pmol of DNA encoding FRB-NFluc and CFlucFKBP, and $1 \mu \mathrm{L}$ of RNasin Plus (Promega) in a total of $25 \mu \mathrm{L}$. Solutions were incubated at $37^{\circ} \mathrm{C}$ for $60 \mathrm{~min}$, followed by the addition of either $25 \mathrm{nM}$ rapamycin or vehicle in the case of FKBP/FRB. Samples were assayed for luciferase activity by combining $20 \mu \mathrm{L}$ of translation solution with $80 \mu \mathrm{L}$ of SteadyGlo Luciferase Assay System (Promega). Luminescence readings were taken on a Turner TD20e luminometer using a $3 \mathrm{~s}$ delay and $10 \mathrm{~s}$ integrations, the average of replicate experiments is shown. The final concentration of $\mathrm{ZOP}$ or rapamycin in the assay was $5 \mathrm{nM}$.

Competition Assay to Identify Protein-DNA Target Site Specificity. Duplicate $25 \mu \mathrm{L}$ translations were carried out in
Flexi-Rabbit Reticulocyte Lysate (Promega) according to the manufacturer's protocol using 0.05 pmol of mRNA encoding PBSII-NFluc and CFluc-Zif268, $10 \mu \mathrm{M} \mathrm{ZnCl}$, and $0.5 \mu \mathrm{L}$ of RNasin Plus (Promega) and allowed to incubate for $90 \mathrm{~min}$ at $30{ }^{\circ} \mathrm{C}$ in the presence of $750 \mathrm{pM}$ Z0P dsDNA target. Following translation and firefly luciferase reassembly, increasing concentrations of each Zif268 hairpin DNA being tested were added followed by a $30 \mathrm{~min}$ incubation at room temperature. Samples were assayed for luciferase activity by combining 20 $\mu \mathrm{L}$ of translation solution with $80 \mu \mathrm{L}$ of Steady-Glo Luciferase Assay System (Promega). Light emission was monitored 1 min after Steady-Glo addition using a Wallac 1420 VICTOR $3 \mathrm{~V}$ luminometer with a $1 \mathrm{~s}$ integration time.

Dissociation of the Reassembled Pum2-NFluc, CFlucPum1, RNA Ternary Complex. Duplicate $25 \mu \mathrm{L}$ translation reactions were carried out in Rabbit Reticulocyte Lysate (Promega) according to the manufacturer's protocol using 0.1 pmol of mRNA encoding Pum2-NFluc and CFluc-Pum1 and $0.5 \mu \mathrm{L}$ of RNasin Plus (Promega) and allowed to incubate for $90 \mathrm{~min}$ at $30^{\circ} \mathrm{C}$ in the presence of $2.5 \mathrm{nM}$ RNA oligonucleotide target. Following translation and firefly luciferase reassembly, increasing concentrations of a competitor RNA oligonucleotide were added followed by a 30 min incubation at room temperature. Samples were assayed for luciferase activity by combining $20 \mu \mathrm{L}$ of translation solution with 80 $\mu \mathrm{L}$ of Steady-Glo Luciferase Assay System (Promega). Light emission was monitored $1 \mathrm{~min}$ after Steady-Glo addition using a Turner TD-20e luminometer with a $3 \mathrm{~s}$ delay and a $10 \mathrm{~s}$ integration time.

Detection of Small-Molecule and Peptide Modulators of Protein-Protein Interactions. Duplicate $25 \mu \mathrm{L}$ translation reactions were carried out in Rabbit Reticulocyte Lysate (Promega) according to the manufacturer's protocol using 2 pmols of mRNA encoding either FRB-NFluc and CFlucFKBP, PKI-NFluc and CFluc-PKA, or p300-NFluc and CFlucHIF-1a and $0.5 \mu \mathrm{L}$ of RNasin Plus (Promega) and allowed to incubate for $90 \mathrm{~min}$ at $30{ }^{\circ} \mathrm{C}$. For analysis of the p300/HIF-1a interaction $10 \mu \mathrm{M} \mathrm{ZnCl}_{2}$ was added to the translation reaction. Following translation, lysates were diluted 1:4 with PBS containing $1 \%$ BSA followed by the addition of increasing concentrations of either rapamycin in DMSO, PKI, or chetomin in DMSO followed by a 30 min incubation at room temperature. Samples were assayed for luciferase activity by combining $20 \mu \mathrm{L}$ of translation solution with $80 \mu \mathrm{L}$ of SteadyGlo Luciferase Assay System (Promega). Light emission was monitored $1 \mathrm{~min}$ after Steady-Glo addition using a Wallac 1420 VICTOR $3 \mathrm{~V}$ luminometer with a $1 \mathrm{~s}$ integration time.

Reassembly of Split-Firefly Luciferase in Water-in-Oil Emulsions. Water-in-oil emulsions were prepared in $2 \mathrm{~mL}$ round-bottom cryogenic vials by adding $50 \mu \mathrm{L}$ of aqueous phase, over $2 \mathrm{~min}$, into $950 \mu \mathrm{L}$ of mineral oil containing $4.5 \%$ Span 80 and $0.5 \%$ Tween 80 while stirring at $1150 \mathrm{rpm}$ using a $2 \mathrm{~mm} \times 9 \mathrm{~mm}$ stir bar. Stirring was continued for one minute after the complete addition of the aqueous phase. Translations were prepared on ice using Wheat Germ Plus extract (Promega) according to the manufacturer's protocol using 4 pmol of each mRNA encoding either PKI-NFluc, CFluc-PKA, or both and $0.5 \mu \mathrm{L}$ of RNasin Plus (Promega). For DNA-dependent reassembly, 4 pmol of each mRNA encoding for CFlucZif268 and PBSII-NFluc, $10 \mu \mathrm{M} \mathrm{ZnCl}_{2}, 0.5 \mu \mathrm{L}$ of RNasin Plus (Promega), and either $25 \mathrm{nM}$ Z0P target DNA or no DNA were mixed in a total of $50 \mu \mathrm{L}$. Emulsions were prepared using the ice-cold translation as the aqueous phase. Emulsions were incubated at $25^{\circ} \mathrm{C}$ for $2 \mathrm{~h}$ and assayed by combining $20 \mu \mathrm{L}$ of emulsion with $80 \mu \mathrm{L}$ of Steady-Glo (Promega). Luminescence 
readings were taken on a Turner TD20e luminometer using a 3 $\mathrm{s}$ delay and a $10 \mathrm{~s}$ integration time.

Acknowledgments - We thank C. A. Aspinwall, S. S. Gambhir, A. Miyawaki, B. Z. Olenyuk, and S. S. Taylor for constructs containing full-length firefly luciferase, FRB and FKBP, Venus, p300, and PKA, respectively. This research was supported by R21CA122630 (NIH). J.R.P. and B.W.J. were supported by an NIH training grant. J.R.P also thanks the ARCS Foundation. We thank Scott Meyer for the PKI-peptide, and Elizabeth Mansfield for help with microscopy. Models were rendered using PyMol; DeLano, W. L. at http://www.pymol.org

Supporting Information, including details of cloning, assay conditions and protocols, and the complete Reference 48, is presented in the following pages. 
A General and Rapid Cell-Free Approach for the Interrogation of ProteinProtein, Protein-DNA, and Protein-RNA Interactions and their Antagonists Utilizing Split-Protein Reporters

Jason R. Porter, Cliff I. Stains, Benjamin W. Jester, and Indraneel Ghosh ${ }^{*}$

Department of Chemistry, University of Arizona, Tucson AZ 85721
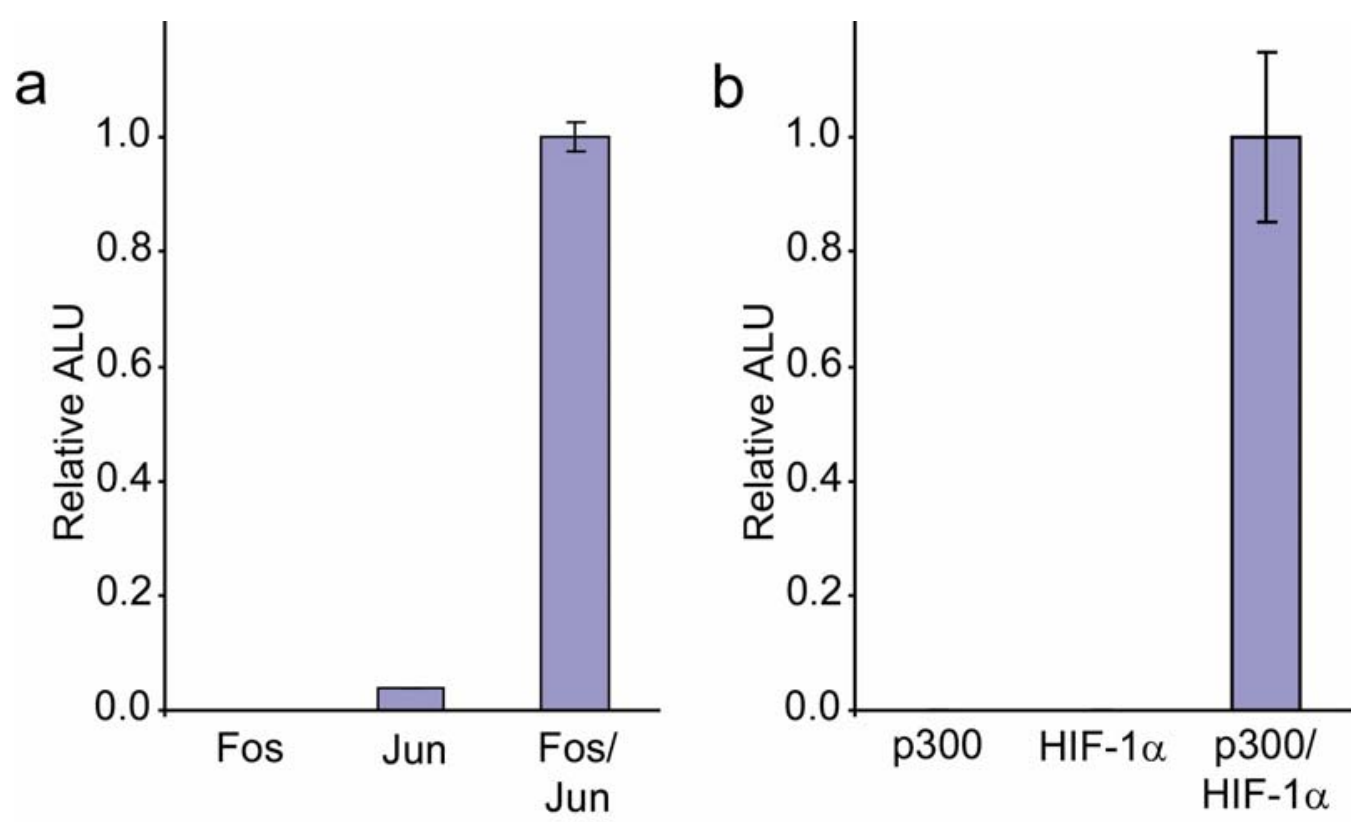

Supplementary Figure S1. Detection of Fos/Jun and p300/HIF-1 $\alpha$ interactions. (a) Association dependent firefly luciferase reassembly of Fos-NFluc and CFluc-Jun fusions utilizing in vitro transcribed mRNA in a rabbit reticulocyte lysate translation system. A significant signal increase is observed when Fos-NFluc and CFluc-Jun are co-expressed over either fusion protein alone. (b) Association dependent firefly luciferase reassembly of p300-NFluc and CFluc-HIF- $1 \alpha$ fusions utilizing in vitro transcribed mRNA in a rabbit reticulocyte lysate translation system. A significant signal increase is observed when p300-NFluc and CFluc-HIF-1 $\alpha$ are co-expressed as compared to either fusion protein alone. 


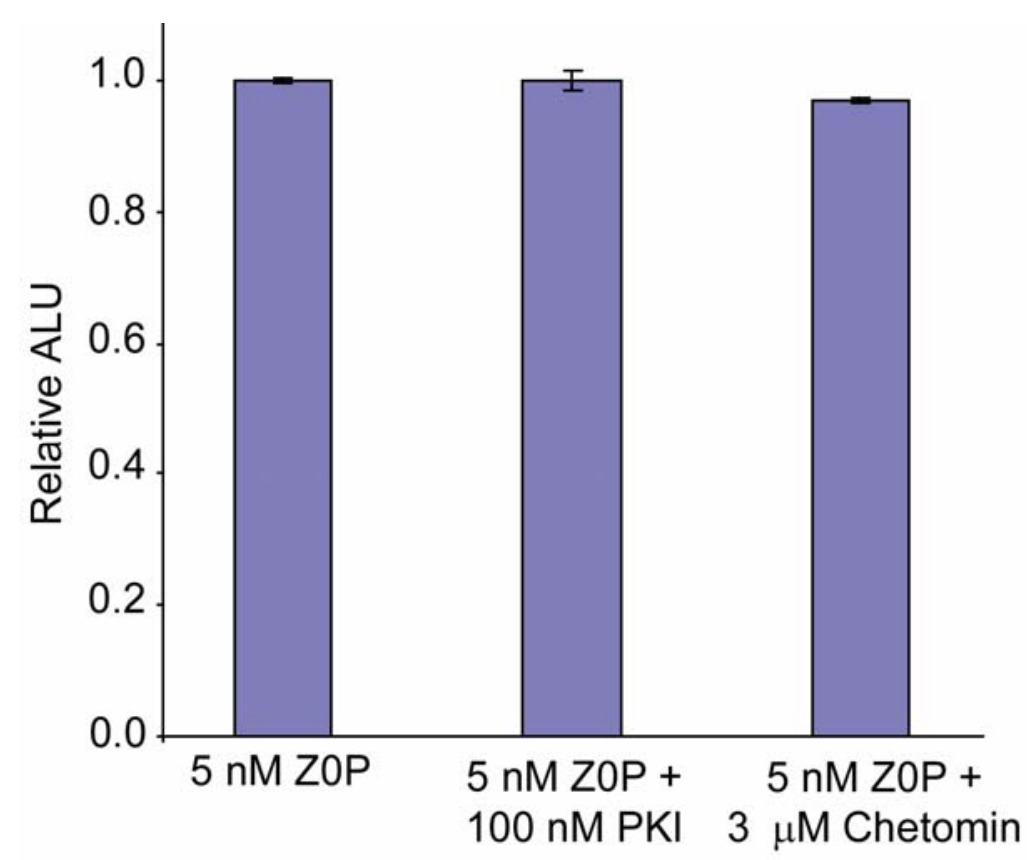

Supplementary Figure S2. Interrogating off target effects of the PKI (peptide) and chetomin (small molecule) protein-protein interaction inhibitors on the DNA dependent firefly luciferase reassembly system (ternary complex: PBSII-NFluc, CFluc-Zif268, and $5 \mathrm{nM}$ target dsDNA oligonucleotide). No decrease in signal is observed upon addition of either $100 \mathrm{nM}$ PKI or $3 \mu \mathrm{M}$ chetomin to the ternary complex. 


\begin{tabular}{|c|c|c|c|}
\hline Reassembly Pairs & Split-Protein Fusion & Agonist & Antagonist \\
\hline $\begin{array}{l}\text { NVenus-Zif268 } \\
\text { PBSII-CVenus }\end{array}$ & $\begin{array}{c}\text { Venus }(1-157) \\
\text { Venus }(158-238)\end{array}$ & ZOP dsDNA Target & \\
\hline $\begin{array}{l}\text { N } \beta \text { Lac-Zif268 } \\
\text { PBSII-C } \beta \text { Lac }\end{array}$ & $\begin{array}{l}\text { BLactamase (26-196) } \\
\beta \text { LLactamase (198-290) }\end{array}$ & ZOP dsDNA Target & \\
\hline $\begin{array}{l}\text { PBSII-NFluc } \\
\text { CFluc-Zif268 }\end{array}$ & $\begin{array}{l}\text { Firefly Luciferase }(2-416) \\
\text { Firefly Luciferase }(398-550)\end{array}$ & ZOP dsDNA Target & hpDNA-Zif268 \\
\hline $\begin{array}{l}\text { NFluc-Zif268 } \\
\text { PBSI-CFluc }\end{array}$ & $\begin{array}{l}\text { Firefly Luciferase (2-398) } \\
\text { Firefly Luciferase (394-550) }\end{array}$ & ZOP dsDNA Target & \\
\hline $\begin{array}{l}\text { NGluc-Zif268 } \\
\text { PBSII-CGluc }\end{array}$ & $\begin{array}{l}\text { Gaussia Luciferase (17-109) } \\
\text { Gaussia Luciferase (110-185) }\end{array}$ & ZOP dsDNA Target & \\
\hline $\begin{array}{l}\text { Pum2-NFluc } \\
\text { CFluc-Pum1 }\end{array}$ & $\begin{array}{l}\text { Firefly Luciferase }(2-416) \\
\text { Firefly Luciferase }(398-550)\end{array}$ & ss 5'-CAUGGUGUAUAUAGUCUUUUGAUAUAGCGGC-3' & ss 5'-CCAGAAUUGUAUAUAUUCG-3' \\
\hline $\begin{array}{l}\text { MBD2-NFluc } \\
\text { CFluc-Zif268 }\end{array}$ & $\begin{array}{l}\text { Firefly Luciferase (2-416) } \\
\text { Firefly Luciferase (398-550) }\end{array}$ & 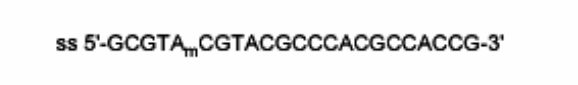 & \\
\hline $\begin{array}{l}\text { PKI-NFluc } \\
\text { CFluc-PKA }\end{array}$ & $\begin{array}{l}\text { Firefly Luciferase (2-416) } \\
\text { Firefly Luciferase (398-550) }\end{array}$ & & PKI Peptide \\
\hline $\begin{array}{l}\text { FRB-NFluc } \\
\text { CFluc-FKBP }\end{array}$ & $\begin{array}{l}\text { Firefly Luciferase (2-416) } \\
\text { Firefly Luciferase (398-550) }\end{array}$ & Rapamycin & \\
\hline $\begin{array}{l}\text { p300-NFluc } \\
\text { CFluc-Hif1 } \alpha\end{array}$ & $\begin{array}{l}\text { Firefly Luciferase (2-416) } \\
\text { Firefly Luciferase (398-550) }\end{array}$ & & Chetomin \\
\hline $\begin{array}{l}\text { Fos-NFluc } \\
\text { CFluc-Jun }\end{array}$ & $\begin{array}{l}\text { Firefly Luciferase }(2-416) \\
\text { Firefly Luciferase }(398-550)\end{array}$ & & \\
\hline
\end{tabular}

Supplementary Table S1. Z0P dsDNA Target (5'-GCGTAGCGTGGGCGGTGTGGAA ACACCG-'3)Protein fusions, reporter fragments, agonists, and antagonists used.

\section{Supplementary Methods}

Fos/Jun and p300/HIF-1 $\alpha$ association dependent reassembly of firefly luciferase. Duplicate $25 \mu \mathrm{L}$ translations were carried out in Flexi-Rabbit Reticulocyte Lysate (Promega) according to the manufacturer's protocol using 2 pmol of each mRNA encoding for either Fos-NFluc, CFluc-Jun, or both, and $0.5 \mu \mathrm{L}$ of RNasin Plus (Promega). Translations were incubated at $30{ }^{\circ} \mathrm{C}$ for 90 minutes and assayed by combining $20 \mu \mathrm{L}$ of translation solution with $80 \mu \mathrm{L}$ of Steady-Glo Luciferase System (Promega). Light emission was monitored using a Turner TD-20e luminometer with a 3 second delay and a 10 second integration time.

Duplicate $25 \mu \mathrm{L}$ translations were carried out in Flexi-Rabbit Reticulocyte Lysate (Promega) according to the manufacturer's protocol using 2 pmol of each mRNA encoding for either p300-NFluc, CFluc-HIF-1 $\alpha$, or both, $10 \mu \mathrm{M} \mathrm{ZnCl}$ and $0.5 \mu \mathrm{L}$ of RNasin Plus (Promega). Translations were incubated at $30{ }^{\circ} \mathrm{C}$ for 90 minutes and assayed by combining $20 \mu \mathrm{L}$ of translation solution with $80 \mu \mathrm{L}$ of Steady-Glo Luciferase System (Promega). Light emission was monitored using a Turner TD-20e luminometer with a 3 second delay and a 10 second integration time.

Determination of off target effects of PKI and chetomin on signal generation. Duplicate $25 \mu \mathrm{L}$ translations were carried out in Flexi-Rabbit Reticulocyte Lysate (Promega) according to the manufacturer's protocol using 2 pmol of each mRNA encoding for PBSII-NFluc (residues 2-416) and CFluc-Zif268 (residues 398-550), $10 \mu \mathrm{M}$ 
$\mathrm{ZnCl}_{2}, 0.5 \mu \mathrm{L}$ of RNasin Plus (Promega), and $25 \mathrm{nM} \mathrm{Z0P}$ target DNA (Table S1). Translations were incubated at $30{ }^{\circ} \mathrm{C}$ for 90 minutes followed by the addition of either 10 $\mu \mathrm{M}$ PKI, $300 \mu \mathrm{M}$ chetomin, or DMSO and allowed to incubate at room temperature for 30 minutes. Light emission was assayed by adding $20 \mu \mathrm{L}$ of translation to $80 \mu \mathrm{L}$ of Steady-Glo Luciferase Assay System (Promega). Final concentrations in the assays were $5 \mathrm{nM}$ DNA, $5 \mathrm{nM}$ DNA plus $100 \mathrm{nM}$ PKI, and $5 \mathrm{nM}$ DNA and $3 \mu \mathrm{M}$ chetomin. Light emission was monitored 1 minute after Steady-Glo addition using a Wallac 1420 VICTOR $3^{\mathrm{TM}} \mathrm{V}$ luminometer with a 1 second integration time.

\section{Complete Reference 48 Citation}

Kung, A. L.; Zabludoff, S. D.; France, D. S.; Freedman, S. J.; Tanner, E. A.; Vieira, A.; Cornell-Kennon, S.; Lee, J.; Wang, B. Q.; Wang, J. M.; Memmert, K.; Naegeli, H. U.; Petersen, F.; Eck, M. J.; Bair, K. W.; Wood, A. W.; Livingston, D. M. Cancer Cell 2004, 6, 33-43. 